\title{
Investigating Reading Challenges Faced by EFL Learners at Elementary Level
}

\author{
Raja Muhammad Ishtiaq Khan, ${ }^{1 *}$ Muhammad Shahbaz, ${ }^{2}$ Tribhuwan \\ Kumar, ${ }^{3}$ Imran Khan ${ }^{4}$ \\ ${ }^{1,4}$ Majma'ah University, Zulfi - Kingdom of Saudi Arabia, ${ }^{2}$ Department of English, GC \\ Women University Sialkot, Sialkot - Pakistan, ${ }^{3}$ College of Science and Humanities, \\ Prince Sattam Bin Abdulaziz University, Sulail - Kingdom of Saudi Arabia \\ ${ }^{*}$ Corresponding Author \\ Email: r.khan@mu.edu.sa \\ DOI: 10.18326/rgt.v13i2.277-292
}

Submission Track:

Received: 30-05-2020

Final Revision: 13-10-2020

Available Online: 01-12-2020

Copyright (C) 2020 Raja Muhammad Ishtiaq Khan, Muhammad Shahbaz, Tribhuwan Kumar, Imran Khan

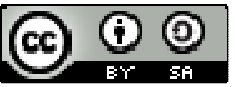

This work is licensed under a Creative Commons Attribution-ShareAlike 4.0 International License.

\begin{abstract}
It is hard to ignore the importance of reading skills for desired proficiency in foreign languages. Reading can be beneficial for learners to immerse themselves in the target language and learn it efficiently. In EFL contexts like Saudi Arabia, learners face many challenges in reading skills. The main purpose of this research was to explore reading problems of elementary level students and causes of the readings skills inabilities. Following random and convenience sampling techniques; this mixed method research obtained quantitative data from 290 elementary level students and qualitative data from nine teachers and supervisors. The analysis of quantitative data from the reading test and checklist and qualitative data retrieved from interviews suggest that students considerably perform relatively low in reading skills, and the main reasons are poor vocabulary, incorrect pronunciation, wrong spellings, slow reading pace and flawed grammar. These five areas account for more than $90 \%$ of the challenges faced by learners in reading skills. Based on evidence from this research, we suggest that policymakers, teachers and students should focus on these five areas for solving the issues related to the reading skills. Although other avenues are essential, these items demand special attention to develop reading skills of EFL learners in Saudi Arabia and elsewhere in the world.
\end{abstract}

Keywords: reading skill; elementary level; reading pace; EFL 


\section{INTRODUCTION}

Reading skills feature the most prominent skills of language learning and teaching, particularly in foreign language learning. It is one of the essential elements in language learning that needs mastery to grasp the required comprehension. In reading skills reader requires to look at the printed or electronic version characters, alphabet, punctuation, and exclamation mark to function his cognitive skill to attain the meaning and understand the message of a writer. Reading skills prepare and develops the understanding of readers and learners (DeMan, 1979). The importance of reading relies on the fact that from reading skills, learners get an eminent part of language learning as it involves almost all features that a foreign language demands. Learners are unable to read because of their incompetency in vocabulary knowledge, pronunciation and accent, grammar, listening and speaking (Khan et al., 2019; Schmitt \& Schmitt, 2020; Shahbaz \& Khan, 2017). Reading inability occurs when learners are not willing to read because of the lack of motivation, burden, and when they consider reading as an exasperating job (Shahbaz et al., 2016). The fact is asserted by Zebrowitz (2018) by indicating that the majority of learners are unable to read properly because of their unwillingness to read.

Likewise, Saudi EFL learners also face problems in reading skills and their reading competency is not at the desired stage (Al Asmari \& Javid, 2018). Most of the learners in the region even face problems in recognizing the basic words of the English language (ElNaggar, 2020). They also are unable to identify the basic notions of the reading skills and take even more time reading short texts in EFL classes. Therefore, it is necessary to make the learners efficient in reading at the elementary level. This notion is also active in the field of EFL research in developed countries, particularly in China, Australia, America, and Canada.

The ability to comprehend and understand the written text well relies on the vocabulary knowledge and phonology of the target language. Most researchers, scholars, instructors, and teachers indicate that vocabulary can foster the process of reading skills. Vocabulary proficiency have a vital impact on reading skills (Lee \& Pulido, 2017). Moreover, good vocabulary knowledge is a key predictor of reading skills and pronunciation efficiency (Braze et al., 2016). It is also noteworthy that through the course of daily life conversation, 
the learners can acquire vocabulary knowledge at an early age. At this stage, learners not only learn new words, but they also try to utilize these words efficiently. Here they try to decode the words for their usage in developing their spoken abilities. In fact, by doing so, they may practice and improve their listening, speaking, reading, and writing skills. So, at the onset, they need to understand everyday language vocabulary.

Researchers (Dewanti, 2020; Harris et al., 2017; Nag \& Narayanan, 2019; Ouellette \& Sénéchal, 2017) have revealed that at the early stage of learning language, reading skill, can be developed by mastering spellings. The proficiency in spelling can help to clear pronunciation and expansion of vocabulary learning, and this results in the development of comprehension skills (Ehri, 2014). Without sound-spelling skills, learners cannot enhance their reading abilities effectively. Learners of elementary level are facing problems for the enhancement of their spellings. Another principal aspect is the retention of spelling, but the fact is that once they identify correct spelling and develop the retention of spelling expertise, then it is fairly comfortable for learners to boost this reading efficiency and speed. This fact is endorsed by Bryant and Goswami (2016) as once learners grasp their skills in reading then they will learn new words quite easily by means of relating words with other forms in reading. The awareness of the sound and spelling system is one of the exponential elements in language learning, particularly in reading skills. Both reading and spellings are regarded as the uniform verges of a coin (Chua et al., 2016; Donovan \& Marshall, 2016).

Numerous scholars (Alkhaleefah, 2017; Keezhatta \& Omar, 2019; Widiyastuti, 2018) have discussed the difficulties that learners encounter during their reading skills, and most of them have highlighted the same issue that hurdles the process of effective reading in FEL context. Unlike other skills, EFL reading skill is not a natural phenomenon, and learners need to make purposeful efforts by combining reading with other skills. Another key aspect to consider is the mechanism of alphabets and sounds of the words (Yule, 2016). Every language has its way of pronunciation; even while silent reading, learners follow the proper system of pronunciation as we use our organ of speech while reading text. This is a notable fact that listener can hear our words that we produce silently (Kim et al., 2015). The basic background of phonetics and phonology also have an impact on reading skills. The majority of EFL learners' 
have poor capabilities in reading skill, and they remain at the static stage because of this unawareness (Alrabai, 2016). This is the most discussed cause of poor performance in reading skills in primary education. This aspect is associated with the reading at the level of initial words.

Reading skill is a mechanism of understanding and comprehending the text and other information associated with it. To comprehend completely, knowledge of grammar is also essential in developing reading skills. Grammatical knowledge can make the process of understanding messages of the writer efficient (Klingelhofer \& Schleppegrell, 2016). Literature is abundant in studies that establish the important aspect of grammatical knowledge for the progression of reading skills. Therefore, the role of syntactic knowledge remains crucial by any means of reading skills. The true meaning and real sense of sentences and paragraphs count on a clear understanding of grammar. Akbari (2014) signified that with the aid of the functional knowledge of grammar learners can have a persuasive understanding of reading skills successfully.

Many researchers (Schwanenflugel \& Kuhn, 2016; Taguchi et al., 2016; Veenendaal et al., 2015) asserted that reading speed is the capability that can advance the process of reading skills accurately and smoothly. In most of the institutions, reading fluency is the most neglected part of language learning in classrooms at the elementary level. The habit of repetition of the test and formative feedback fosters the fluency of reading skills (Gorsuch et al, 2015). Many learners struggle in the development of reading skills just because of the fluency problem.

The recent and relevant research suggests that Saudi learners appear to have an inadequate vocabulary that results in poor performance in learning language skills. They also lack the proper and basic comprehension of simple texts at the school level (al-Qahtani, 2016a, 2016b; Gorsuch et al, 2015). These factors are ascribed to many other factors related to procedure of language learning.

Alkhaleefah (2017) conducted a study with aims to indicate the comprehensive and detailed investigation of a small number of learners who have poor reading proficiency. Qualitative analysis of data identified that learners have difficulty in explicit text reading. Though the study indicated that learners have to face challenges in the EFL context, but it was limited to 
relatively small samples, and hence the findings cannot be compared with extensive studies. Similarly, Al Nooh (2013) carried out a study on a set of Saudi secondary level learners to indicate the learner's problems in their reading skills. The result of study explained that most of the learners face hindrances in reading fluency, comprehension of a text, and retention of new words or challenging variables in the reading skills. Most of the participants stated that the understanding sounds created hurdles in their fluent reading. The most prominent factor is that reading culture is not so developed in Saudi institutions; even some learners are unable to read short segments of text.

Mohammed and Ab Rashid (2019) also reviewed the sources of difficulties encountered by Saudi EFL learners. Data was sorted through a questionnaire. The results reveal that the learns largely feel that the are several factors that cause problems in reading comprehension including, cultural impact, teacher style of teaching and difficulty levels of the textbooks. In another study, (alMansour \& al-Shorman, 2011) indicated similar findings where lack of adequate vocabulary and the environmental aspect is the most problematical issue in developing reading skills. Keezhatta and Omar (2019) conducted a research study in the MALL background. They also noticed that Saudi EFL learners have poor reading skills and use of technology can improve the reading skills greatly. Likewise, Khan et al. (2018) asserted that learners language problem can be improved by the use of technology.

The attention in carrying out this research originates from the disappointments and insufficient reading capabilities of learners. The gap "incompetency in reading skills" is vital from the published literature and personal experience of teaching in Saudi Arabia. Hence, investigation of elementary level EFL learners' ability in reading skills has been mainly unnoticed in previous research studies. The present study is an effort to underscore the main causes of poor reading ability. To this end, the study aims to answer the following question.

What are the causes of reading inabilities of elementary level learners in KSA? This research question further explores the role of vocabulary, grammar, pronunciation and spellings in reading skills of learners at the elementary level in KSA. 


\section{RESEARCH METHOD}

The current research study adopted the mixed methods design. This allowed researchers to combine different approaches. The mixed method refers to as "empirical research that involves the collection and analysis of both qualitative and quantitative data" (Johnson \& Onwuegbuzie, 2004). Moreover, Creswell and Plano Clark (2011) stated that this method allows researchers a better notch in supporting the formulated ideas than if a single method were implemented in particular studies. Moreover, they also mentioned an assortment of essential features that acme main fundamentals in mixed methods research. Data were obtained from the learners by using a self-developed test, a checklist for learners' reading speed, and interviews from teachers to gain more insight about the reading inabilities. The test was developed and sent to different experts and researchers in the field for its suitability for grading learners' reading proficiency problems. The experts are teaching English at different levels having 5 to 15 years of EFL experience. After getting feed-back from experts, test was administered to elementary level learners. Moreover, a checklist was also used to identify the reading speed problems of learners.

\section{Participants}

The participants of the present research study are seven elementary level classes comprising $290 \mathrm{EFL}$ learners. All the learners were male participants whose native and mother tongue is Arabic. The age of learners ranges between 16 to 18 years. Their experience of learning or speaking a foreign language outside of the classroom was limited, but some of them used social media or television to watch some English language-oriented programs. Nine Saudi EFL Elementary level instructors and three EFL supervisors also participated in the current research study. Instructors were selected on the basis of their foreign language teaching experience, teaching level, and their readiness to take part in diagnosing the reading problems of learners. The purpose of conducting the interviews with the study was to get teachers' perspectives on the learners' reading abilities.

\section{Instruments}

A test was designed to interpret the learners' reading capabilities after going through reading efficiency, checking soft-wares and research studies. 
After seeking advice and suggestions from the experts in the field of EFL, the test was administered to 30 learners to test and retest the process. To check the learners reading speed and pronunciation, and checklist was designed after reviewing a wide range of reading taxonomies (Angelelli et al., 2014; Chiang \& Liu, 2011; Marual, 2015; Stodden et al., 2012). After conducting the test and reading proficiency checklist, the interviews with instructors were arranged to get the instructors' and supervisors' views about the level of their students. The length of each session of the interview was between 12 to 20 minutes and a detailed interview protocol was prepared to keep the process of the interview alive and purposeful.

\section{Data Analysis}

The purpose of the current study was to point out the hurdles that Saudi Elementary level learners face during their course of learning English language. Data gathered from self-developed test, checklist and instructors' interviews were further analyzed. The test was developed in keeping in view the standard of elementary level learners' textbooks. The test was used to locate the grammar, vocabulary and spelling problems in learning English. Similarly, after administring the test, data for fluency and pronunciation was collected by using checklists. All data collected were inserted into SPSS 21.0 for statistical analysis of the data. By using SPSS, percent, valid percent, cumulative percent, and frequencies of the collected data marked for the purpose of identification of the indicted problems. Furthermore, the data were coded into (Poor, P: Weak, w; below Average; BA, Average, A and Excellent, E). For each coded data, a range of the percent was assigned to classify the data in terms of statistics to sort out the hurdles in reading proficiency. The following rubric was utilized to code the percentage of the data (Table 1).

Table 1. Range of Percentage for Assigned Categories

\begin{tabular}{lll}
\hline No. & Tittle & Percent \\
\hline 1 & Poor & $1-19$ \\
2 & Weak & $20-39$ \\
3 & Below Average & $40-59$ \\
4 & Average & $60-79$ \\
5 & Excellent & $80-100$ \\
\hline
\end{tabular}


Table 2. Vocabulary Role in Learners' Reading Skills

\begin{tabular}{lllll}
\hline \multicolumn{2}{l}{ Vocabulary Role } & & \\
\hline Scale & Frequency & Percent & Valid Percent & $\begin{array}{l}\text { Cumulative } \\
\text { Percent }\end{array}$ \\
\hline P & 56 & 19.1 & 19.1 & 19.9 \\
W & 68 & 23.4 & 23.4 & 31.2 \\
BA & 72 & 24.8 & 24.8 & 55.2 \\
A & 55 & 18.9 & 18.9 & 83.8 \\
E & 39 & 13.8 & 13.8 & 69.1 \\
Total & 290 & 100 & 100 & \\
\hline
\end{tabular}

Table 2 illustrates the full description of the part of the vocabulary in the reading skills of 290 EFL learners. It is evident from the SPSS analysis that the occurrence of poor indication of the results or those who did not try to attempt the whole test is 56 . This marginal $19.1 \%$ is the total percent and valid percent of the studied sample. The occurrence of week leaners who solved the complete test but did not reach the standard of passing the test is 68 . This $23.4 \%$ and valid percent are 68 out of total participants of 290 learners. More likely, the frequency of below average; sample has close relation with the sample who did not pass the test. This frequency is 72 with a valid percentage of 24.8 in 290 learners, which is at quite an edge of failing the test.

Contrarily, the frequency of average learners in the analysis is 55 , which is quite far from the learner who did not reach the required standard of passing the test. The valid percent and percent of average learners are 18.9. In the same way, the learners at excellent numbers are quite less as compared to learners who performed poorly on the test. There is a clear indication for instructors and relevant authorities to look into this consideration, which is an important aspect of reading skills in particular and in language learning in general.

It is undeniable that spellings in reading skills take the role of the backbone in learning process. The key factor is that spelling develops the habit of reading. Table 3 asserts that a large number of learners have reading inability just because they are not efficient in indicating or producing accurate spelling. The SPSS analyses portray that 88 among 290 learners have poor spelling abilities, and their valid percentage is 30.4 , which is relatively high as compared to the average and excellent learners. Whereas on the other side of that frequency table shows 
that the number of average learners and excellent grade learners are 38, and 26 respectively, with valid percentage of 13.4 and 9.4, which is quite less in comparison with week learners. Learners whose reading skills are not up to mark are weak in the spelling aspect of words that creates hurdles in the process of effective reading skills. This asserts that every student has different spelling proficiency and the acceptable percent is relatively appeared low in the data analysis. Furthermore, only $9.4 \%$ of the participants' spellings proficiency seemed fairly well.

Table 3. The Role of Spelling in Reading Proficiency

\begin{tabular}{lllll}
\hline \multicolumn{2}{l}{ Spelling Role } \\
\hline Scale & Frequency & Percent & Valid Percent & Cumulative Percent \\
\hline P & 88 & 30.4 & 30.4 & 22.2 \\
W & 96 & 38.4 & 38.4 & 61.3 \\
BA & 41 & 14.1 & 14.1 & 83.8 \\
A & 39 & 13.4 & 13.4 & 94.1 \\
E & 26 & 9.4 & 9.4 & 100 \\
Total & 290 & 100 & 100 & \\
\hline
\end{tabular}

Table 4. The Role of Pronunciation in Reading Inabilities

\begin{tabular}{lllll}
\hline \multicolumn{2}{l}{ Pronunciation Role } & & \\
\hline Scale & Frequency & Percent & Valid Percent & Cumulative Percent \\
\hline P & 86 & 29.6 & 29.6 & 20.2 \\
W & 99 & 34.2 & 34.2 & 64.3 \\
BA & 40 & 13.7 & 13.7 & 81.8 \\
A & 38 & 13.1 & 13.1 & 96.1 \\
E & 27 & 9.3 & 9.3 & 100 \\
Total & 290 & 100 & 100 & \\
\hline
\end{tabular}

Table 4 presents the statistical interpretation of the pronunciation that learners come across during their reading skills. It is apparent from the analysis that a considerable number of EFL learners are unable to pronounce the words correctly during the course of reading. The frequency of the poor performer learners is 86 followed by 99 -week learners. The percent, and valid percent of poor, and week learners is 29.6 and 34.2 respectively. The percent and valid percent of excellent and average learners is 13.1 and 9.3 respectively. This is 
quite noticeable as most of the learners are poor in pronunciation that results in reading inability to a great extent.

From Table 4, it is also predictable that reading skills are also affected by the functional grammar. The numerical value shows that most of the learners are at a poor stage. The frequency, percent, and valid percent is $123,42.5$, and 42.5 respectively, which is in the highest place in the table, among other reading inabilities. The frequency of week leaners is 14 with a valid percent of 5.3. This asserts that only small numbers of learners are efficient in reading skills.

Table 5. The Role of Grammar in Reading Inabilities

\begin{tabular}{lllll}
\hline \multicolumn{4}{l}{ Grammar Role } \\
Scale & Frequency & Percent & Valid Percent & Cumulative percent \\
\hline P & 123 & 42.5 & 42.5 & 43.2 \\
W & 89 & 30.9 & 30.9 & 67.4 \\
BA & 41 & 14.7 & 14.7 & 83.8 \\
A & 23 & 7.1 & 7.1 & 95.1 \\
E & 14 & 5.3 & 5.3 & 100 \\
Total & 100 & 100 & 100 & \\
\hline
\end{tabular}

\section{Teachers' and supervisors' Perceptions about Reading}

To understand the full depiction of learners' reading inabilities, nine instructors and three supervisors were interviewed. The purpose of the interviews was to inquire about their perception of learners' reading skills and the causes behind the reading incompetency. Most of the instructors indicated that learners' reading skills are commonly poor. They proclaimed that a substantial number of them are unaware of reading letters correctly. The general reason they specified that most of the learners have limited vocabulary, and they need to train the learners for at least two to three weeks to develop their basic vocabulary skills. This is mainly because of their exposure to the English language is minimal. All the learners speak Arabic language when they leave the classrooms, and even some don't try to speak in the class. Another important factor came out that poor reading skills account for the lack of concentration of reading core values; they just pay attention to grammar and vocabulary during their teaching process. They also asserted that fluency, 
pronunciation, vocabulary, and grammar knowledge insufficiency also have a significant impact on learners' reading skills. Some of them blamed the lack of exposure of English language out of the formal classroom, teacher-centred teaching and their fellow teachers are also responsible for this factor. If we focus on five major factors and uproot problems related to them, then we might be in a good position to offer better solutions to reading inefficiency. The graph below illustrates the instructors and supervisors' perceptions about the learners' reading skills.

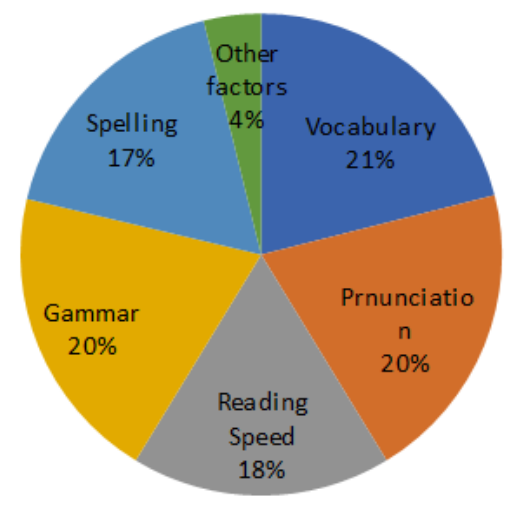

Figure 1. Instructors' and Supervisors' Perceptions about Reading Problems

\section{FINDING AND DISCUSSION}

The present study examined learners' reading skills to understand the learners' existing reading expertise of English language. To accomplish this, the learners were provided with a reading test and checklist about the reading habits and problems. The result obtained from the checklist, reading test and interview of the instructors were analyzed and illustrated in the previous section.

The results of the present study are in line with previous studies, where many studies approve that reading inability is because of the vocabulary, fluency, spelling, and pronunciation (al-Mansour \& al-Shorman, 2011; al-Nooh, 2013; Alkhaleefah, 2017). Vocabulary proficiency is an essential aspect of developing language skills and without the desired level of vocabulary, EFL 
learners face glitches in the production of the required level of language. This asserts that once learners attain the vocabulary expertise, their spelling, fluency, pace of reading text also improve significantly. The present study also establishes a strong agreement with (Abalkhail \& Shawky, 2002; Alshumaimeri \& Almasri, 2012; Rajab \& al-Sadi, 2015) that illustrate that learners have a low tendency to read outside of the formal classrooms and they spend most of the time on social media.

The findings of the study suggest that reading skills need more exploration with extended population and engaging more teachers to compare and design a framework for the improvement of learners' reading habits. Similarly, all the reading programs must be redesigned to inculcate all the basic reading essentials with the textbook. Motivation to reading extra material by the teachers may also result in improving the reading skills. Teachers need to plan some additional reading practice sessions in conventional classes. Reading skills can also be improved by putting some extra efforts on vocabulary teaching with the help of possible available technology for the retention of vocabulary knowledge. Furthermore, the subject instructor should get the training of teaching reading skills at the elementary level to cope up with reading inabilities. A further recommendation is to examine the effects of explicit teaching with the incorporation of blended learning on young learners to identify the learner's language acquisition skills and perceptions.

\section{CONCLUSION}

The results of the reading proficiency test and checklist indicated that Learners face challenges in reading skills. The recognition of vocabulary and knowledge of grammar was the most indicated problem asserted by the learners. Moreover, learners also acknowledged the role of spelling and pronunciation in developing reading skills. The detailed overview of data explored that a greater part of the sample was weak in reading skills because of the lack of the required and suitable vocabulary. This finding is also endorsed by the instructors, who also admitted that mostly they did not consider it useful during the reading process. Another important reason was figured out by the instructors and learners in reading inability was the awareness about the 
knowledge of grammar. A considerable number of learners identified that the reading incompetency is just because of the lack of grammar knowledge. Moreover, the majority of the learners were not able to read words correctly because they could not spell the words. This further became more problematic because of the unusual spellings. Proper spelling retention was also indicated by the instructors. Likewise, pronunciation and fluency were further important elements of poor reading capabilities.[rgt]

\section{REFERENCES}

Abalkhail, B., \& Shawky, S. (2002). Prevalence of daily breakfast intake, iron deficiency anaemia and awareness of being anaemic among Saudi school students. International journal of food sciences and nutrition, 53(6), 519-528.

Akbari, Z. (2014). The role of grammar in second language reading comprehension: Iranian ESP context. Procedia-Social and Behavioral Sciences, 98, 122-126.

al-Asmari, A., \& Javid, C. Z. (2018). Role of content schema in reading comprehension among Saudi EFL Students: EFL Teachers' Perspective and Use of Appropriate Classroom Strategies. International Journal of English Linguistics, 8(4), 96.

Alkhaleefah, T. A. (2017). Saudi EFL Learners' Reported Reading Problems and Strategic Processing of Text Types: A Think-aloud Case Study. Reading Psychology, 38(7), 687-730.

Alrabai, F. (2016). Factors underlying low achievement of Saudi EFL learners. International Journal of English Linguistics, 6(3), 21-37.

Alshumaimeri, Y. A., \& Almasri, M. M. (2012). The effects of using WebQuests on reading comprehension performance of Saudi EFL students. TOJET: The Turkish Online Journal of Educational Technology, 11(4).

Angelelli, P., Marinelli, C. V., \& Burani, C. (2014). The effect of morphology on spelling and reading accuracy: a study on Italian children. Frontiers in psychology, 5, 1373.

Braze, D., Katz, L., Magnuson, J. S., Mencl, W. E., Tabor, W., Van Dyke, J. A., . . . Shankweiler, D. P. (2016). Vocabulary does not complicate the simple view of reading. Reading and writing, 29(3), 435-451. 
Bryant, P., \& Goswami, U. (2016). Phonological skills and learning to read: Routledge.

Chiang, H.-Y., \& Liu, C.-H. (2011). Evaluation of the benefits of assistive reading software: Perceptions of high school students with learning disabilities. Assistive Technology, 23(4), 199-204.

Chua, S. M., Rickard Liow, S. J., \& Yeong, S. H. (2016). Using spelling to screen bilingual kindergarteners at risk for reading difficulties. Journal of learning disabilities, 49(3), 227-239.

Creswell, J. W., \& Plano Clark, V. (2011). Choosing a mixed methods design. Designing and conducting mixed methods research, 53-106.

DeMan, P. (1979). Allegories of reading: figural language in Rousseau, Nietzsche, Rilke, and Proust (Vol. 16): Yale University Press.

Dewanti, S. (2020). A correlative study on reading intensity toward writing skill of eleventh grade students of SMK Negeri 1 Tuntang. (Thesis). available at http://e-repository.perpus.iainsalatiga.ac.id/8696/1/skripsi_ safridadewanti_23030160017-edit\%202.pdf

Donovan, J. L., \& Marshall, C. R. (2016). Comparing the verbal self-reports of spelling strategies used by children with and without dyslexia. International Journal of Disability, Development and Education, 63(1), 27-44.

Ehri, L. C. (2014). Orthographic mapping in the acquisition of sight word reading, spelling memory, and vocabulary learning. Scientific Studies of Reading, 18(1), 5-21.

ElNaggar, A. I. M. (2020). Investigating problems of speaking skill: A case study at Al-Baha University. SSRN Electronic Journal. Available at SSRN 3521868.

Gorsuch, G., Taguchi, E., \& Umehara, H. (2015). Repeated reading for Japanese language learners: Effects on reading speed, comprehension, and comprehension strategies. The Reading Matrix, 15, 18-44.

Harris, K. R., Graham, S., Aitken, A. A., Barkel, A., Houston, J., \& Ray, A. (2017). Teaching spelling, writing, and reading for writing: Powerful evidence-based practices. Teaching Exceptional Children, 49(4), 262-272.

Johnson, R. B., \& Onwuegbuzie, A. J. (2004). Mixed methods research: A research paradigm whose time has come. Educational researcher, 33(7), 14-26.

Keezhatta, M. S., \& Omar, A. (2019). Enhancing reading skills for Saudi Secondary School Students through Mobile Assisted Language Learning (MALL): An 
experimental study. International Journal of English Linguistics, 9(1), 437447.

Khan, R., Radzuan, N., Alkhunaizan, A., Mustafa, G., \& Khan, I. (2019). The Efficacy of MALL Instruction in Business English Learning. International Journal of Interactive Mobile Technologies, 13(8), 60-73.

Khan, R. M. I., Radzuan, N. R. M., Shahbaz, M., \& Ibrahim, A. H. (2018). EFL instructors' perceptions on the integration and implementation of MALL in EFL classes. International Journal of Language Education and Applied Linguistics, 39-50.

Kim, Y.-S., Petscher, Y., \& Foorman, B. (2015). The unique relation of silent reading fluency to end-of-year reading comprehension: understanding individual differences at the student, classroom, school, and district levels. Reading and writing, 28(1), 131-150.

Klingelhofer, R. R., \& Schleppegrell, M. (2016). Functional grammar analysis in support of dialogic instruction with text: scaffolding purposeful, cumulative dialogue with English learners. Research Papers in education, 31(1), 70-88.

Lee, S., \& Pulido, D. (2017). The impact of topic interest, L2 proficiency, and gender on EFL incidental vocabulary acquisition through reading. Language Teaching Research, 21(1), 118-135.

al-Mansour, N. S., \& Al-Shorman, R. e. A. (2011). The effect of teacher's storytelling aloud on the reading comprehension of Saudi elementary stage students. Journal of King Saud University-Languages and Translation, 23(2), 69-76.

Marual, M. (2015). Level of word recognition and reading comprehension: A Basis for a reading program. Asia Pacific Journal of Education, Arts, and Sciences, 1(5), 69-75.

Mohammed, Q., \& Ab Rashid, R. (2019). The sources of reading comprehension difficulties among saudi efl learners. Trends in Social Sciences, 1(1), 7-16.

Nag, S., \& Narayanan, B. (2019). Orthographic knowledge, reading and spelling development in Tamil: the first three years Handbook of literacy in akshara orthography (pp. 55-83): Springer.

al-Nooh, A. (2013). The effectiveness of reading techniques used in a Saudi Arabian secondary school classroom as perceived by students and teachers: A Study of methods used in teaching english and their effectiveness. Arab World English Journal, 4(3). 
Ouellette, G., \& Sénéchal, M. (2017). Invented spelling in kindergarten as a predictor of reading and spelling in Grade 1: A new pathway to literacy, or just the same road, less known? Developmental Psychology, 53(1), 77.

al-Qahtani, A. A. (2016a). Why do Saudi EFL readers exhibit poor reading abilities? English Language and Literature Studies, 6(1), 1.

al-Qahtani, A. A. Y. (2016b). Can creative circles improve reading comprehension and creative thinking of Saudi third-grade middle school EFL learners?

Rajab, H., \& Al-Sadi, A. (2015). An empirical study of reading habits and interests of Saudi university EFL learners. International Journal of Linguistics, 7(2), 1-16.

Schmitt, N., \& Schmitt, D. (2020). Vocabulary in language teaching: Cambridge university press.

Schwanenflugel, P. J., \& Kuhn, M. R. (2016). Reading fluency. Handbook of individual differences in reading: Reader, text, and context, 107-119.

Shahbaz, M., Khan, M. S., Khan, R. M. I., \& Mustafa, G. (2016). Role of self-perceived communication competence and communication apprehension for willingness to communicate in L1 and L2. Journal of Educational and Social Research, 6(1), 158.

Shahbaz, M., \& Khan, R. M. I. (2017). Use of mobile immersion in foreign language teaching to enhance target language vocabulary learning. MIER Journal of Educational Studies, Trends and Practices, 7(1).

Stodden, R. A., Roberts, K. D., Takahashi, K., Park, H. J., \& Stodden, N. J. (2012). Use of text-to-speech software to improve reading skills of high school struggling readers. Procedia Computer Science, 14, 359-362.

Taguchi, E., Gorsuch, G., Lems, K., \& Rosszell, R. (2016). Scaffolding in L2 reading: How repetition and an auditory model help readers. Reading in a Foreign Language, 28(1), 101.

Veenendaal, N. J., Groen, M. A., \& Verhoeven, L. (2015). What oral text reading fluency can reveal about reading comprehension. Journal of Research in Reading, 38(3), 213-225.

Widiyastuti, W. (2018). The use of apples to apples game to improve students'reading comprehension in teaching recount text (a classroom action research of tenth grade of ma al bidayah 2018/2019). Thesis. IAIN Salatiga.

Yule, G. (2016). The study of language: Cambridge University Press.

Zebrowitz, L. (2018). Reading faces: Window to the soul? : Routledge. 